Article

\title{
Pleurotus ostreatus as a Biocatalyst to Obtain Bicyclic Hydroxylactones with Three or Four Methyl Groups
}

\author{
Małgorzata Grabarczyk ${ }^{1, *} \mathbb{D}$, Wanda Mączka ${ }^{1}$, Katarzyna Wińska ${ }^{1}\left(\mathbb{D}\right.$, Adrianna Kondas ${ }^{1}$, \\ Barbara Żarowska ${ }^{2}$, Gabriela Maciejewska ${ }^{3}$, Elżbieta Gębarowska ${ }^{4}$ (D) and \\ Stanisław Jerzy Pietr 4 (D) \\ 1 Department of Chemistry, Wrocław University of Environmental and Life Sciences, Norwida 25, \\ 50-375 Wrocław, Poland \\ 2 Department of Biotechnology and Food Microbiology, Wrocław University of Environmental and Life \\ Sciences, Chełmońskiego 37/41, 51-630 Wrocław, Poland \\ 3 Faculty of Chemistry, Wrocław University of Technology, Wybrzeże Wyspiańskiego 27, \\ 50-370 Wrocław, Poland \\ 4 Department of Plant Protection, Wrocław University of Environmental and Life Sciences, Grunwaldzki Sq. \\ 24a, 50-363 Wrocław, Poland \\ * Correspondence: magrab@onet.pl or malgorzata.grabarczyk@upwr.edu.pl; Tel.: +48-71-320-5252
}

Received: 11 July 2019; Accepted: 25 July 2019; Published: 28 July 2019

check for

Abstract: The purpose of the study was to explore microbial transformations in cultures of basidiomycetes Pleurotus ostreatus, two bicyclic unsaturated lactones occurring in the form of two diastereoisomers. Some of these strains were able to transform unsaturated lactones into four known and three new derivatives. The structures of all lactones were established on the basis of spectroscopic data. Both substrates and products caused a complete inhibition of growth of A. alternata and F. linii strains.

Keywords: unsaturated lactones; hydroxylation; epoxidation; biotransformation

\section{Introduction}

Mushrooms of the Pleurotus genus are the main decomponent of plant residues. They grow mainly on dead wood, which contains lignocellulose compounds needed for their growth. They can also parasitize on living trees, infecting them with white rot [1]. These fungi are applicable in our diet as a source of valuable low fat nutrients. Their fruiting bodies are rich in easily absorbed proteins, carbohydrates, amino acids, B vitamins (thiamine, riboflavin, and niacin), and mineral salts (calcium, phosphorus, and iron) [2-4]. Depending on whether these fungi grow wild or under greenhouse conditions, quantitative proportions of nutrients may vary, due to the nature of the substrate used for the growth of mycelium [2,3,5]. Mushrooms of the Pleurotus genus have found various applications. They are able to accumulate heavy metals, such as lead or copper [6-8], and biodegrade harmful compounds accumulating in the natural environment, such as aflatoxins [9], herbicides [10,11], and plasticizers [12-14]. They are also applicable in biotransformations, where they are mainly used for hydroxylation of natural terpenes and their derivatives. The most frequently observed reaction is the hydroxylation in the allylic position and subsequent oxidation of the alcohol formed [15-18].

Hydroxylactones are compounds often found in nature, especially in plants and marine organisms. These compounds are characterized by a broad spectrum of biological activity, e.g., antibacterial [19,20], cytotoxic [20,21], anti-cancer [22,23], anti-inflammatory [24-26], and antifungal [27]. Isolation of hydroxylactones from natural sources is often complicated and allows the desired compounds to be obtained in small amounts. Biotransformation is an alternative method for their acquisition in which substrates obtained by chemical synthesis are used, e.g., unsaturated lactones. 
During the biotransformation of unsaturated lactones that we have carried out so far, filamentous fungi have been used. As a result, both hydroxylactones and epoxylactones were obtained [28-31]. This time, we decided to use edible mushrooms as biocatalysts. Considering the described ability of Pleurotus fungi to transform terpenes, our aim was to obtain new lactones with potential biological activity.

\section{Results}

Two known unsaturated lactones $\mathbf{1}$ and $\mathbf{2}$ (as mixtures of two diastereoisomers named A and B), whose structures are shown in Figure 1, were used for the biotransformation. The whole cells of seven strains of oyster mushroom Pleurotus ostreatus (Jacq.) P. Kumm were used as biocatalyst.
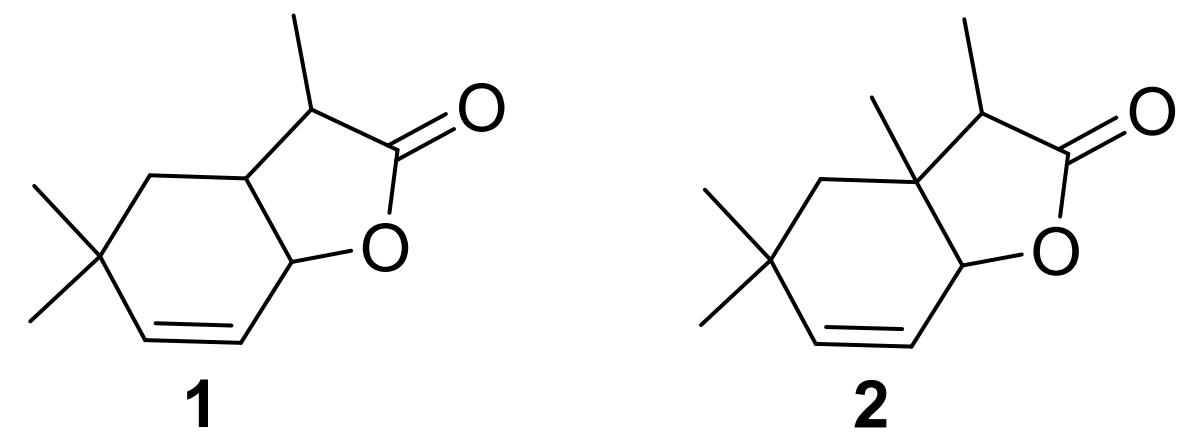

Figure 1. The unsaturated lactones 1 and 2.

During previous studies [31], biotransformations of lactones $\mathbf{1}$ and $\mathbf{2}$ (also as mixtures of diastereoisomers A and B) were carried out using filamentous fungi of the genus Fusarium, Penicilium, Absidia, and Syncephalastrum. As a result, six hydroxylactones and two epoxylactones were obtained. In the current studies, Pleurotus ostreatus strains were used as biocatalysts. These fungi belong to the oyster family, which are, as already mentioned before, known for their ability to hydroxylate terpenoid compounds [15-18]. Seven strains of Pleurotus ostreatus were tested during the screening biotransformation. The purpose of this step was to check whether these strains were capable of conducting the transformation of selected lactones. An attempt was also made to answer the question of whether the products obtained as a result of the biotransformations carried out with the fungi of the Pleurotus ostreatus species would be identical or different to those obtained earlier with the use of filamentous fungi [31]. In the first version, biotransformations were carried out analogously to those carried on filamentous fungi, i.e., taking samples after 7 and 14 days. It turned out, however, that in the case of fungi of the Pleurotus genus, a complete conversion was observed after one week. As a result, the procedure was changed and subsequent trials were collected after 3,5 , and 7 days. The results obtained during the screening tests are provided in the Tables 1 and 2.

Table 1. Results of screening biotransformation of lactone 1 after 3, 5, and 7 days of incubation (in \% according to GC).

\begin{tabular}{ccccc}
\hline Strain & Time (Days) & Lactone $\mathbf{1} \mathbf{A}+\mathbf{B} \mathbf{( \% )}$ & Lactone 3 (\%) & Lactone 4 (\%) \\
\hline \multirow{3}{*}{ PBo6S } & 3 & $27.2+51.0$ & 8.0 & 13.8 \\
& 5 & $3.2+17.6$ & 30.0 & 49.2 \\
& 7 & $0+8.1$ & 31.8 & 60.1 \\
\hline \multirow{3}{*}{ PB63S } & 3 & $25.8+49.2$ & 6.4 & 18.6 \\
& 5 & $20.8+41.2$ & 15.9 & 21.0 \\
& 7 & $14.1+38.2$ & 24.1 & 23.5 \\
\hline \multirow{2}{*}{ PUSAS } & 3 & 100 & 0 & 0 \\
& 5 & $32.0+51.6$ & 5.6 & 10.8 \\
& 7 & $30.3+35.2$ & 9.5 & 25.0 \\
\hline
\end{tabular}


Table 1. Cont.

\begin{tabular}{ccccc}
\hline Strain & Time (Days) & Lactone $\mathbf{1} \mathbf{A}+\mathbf{B}(\mathbf{\%})$ & Lactone 3 (\%) & Lactone 4 (\%) \\
\hline \multirow{3}{*}{ PB7'96 } & 3 & 100 & 0 & 0 \\
& 5 & 100 & 0 & 0 \\
& 7 & 100 & 0 & 0 \\
\hline \multirow{3}{*}{ P112 } & 3 & 100 & 0 & 0 \\
& 5 & 100 & 0 & 0 \\
PxS & 7 & 100 & 0 & 0 \\
& 3 & 100 & 0 & 0 \\
PB8 & 5 & 100 & 0 & 0 \\
& 7 & 100 & 0 & 0 \\
\hline
\end{tabular}

Table 2. Results of screening biotransformation of lactone 2 after 3, 5, and 7 days of incubation (in \% according to GC).

\begin{tabular}{|c|c|c|c|c|c|c|}
\hline Strain & Time (Days) & $\begin{array}{c}\text { Lactone } 2 \mathrm{~A}+\mathrm{B} \\
(\%)\end{array}$ & $\begin{array}{l}\text { Lactone } 5 \\
(\%)\end{array}$ & $\begin{array}{c}\text { Lactone } 6 \\
(\%)\end{array}$ & $\begin{array}{l}\text { Lactone } 7 \\
\quad(\%)\end{array}$ & $\begin{array}{c}\text { Lactone } 8 \\
(\%)\end{array}$ \\
\hline \multirow{3}{*}{ PBo6S } & 3 & $27.4+54.9$ & 10.0 & 7.6 & 0 & 0 \\
\hline & 5 & $3.1+18.3$ & 38.6 & 31.0 & 8.9 & 0 \\
\hline & 7 & $0+0$ & 33.3 & 34.0 & 32.7 & 0 \\
\hline \multirow{3}{*}{ PB63S } & 3 & $9.7+34.2$ & 51.4 & 0 & 4.7 & 0 \\
\hline & 5 & $0+12.4$ & 63.5 & 0 & 24.1 & 0 \\
\hline & 7 & $0+2.4$ & 70.5 & 0 & 27.1 & 0 \\
\hline \multirow{3}{*}{ PUSAS } & 3 & $0+9.3$ & 13.0 & 29.8 & 24.3 & 23.6 \\
\hline & 5 & $0+8.9$ & 8.6 & 13.6 & 30.4 & 38.5 \\
\hline & 7 & $0+6.9$ & 2.8 & 5.0 & 35.2 & 50.1 \\
\hline \multirow{3}{*}{ PB7'96 } & 3 & $0+10.0$ & 18.5 & 43.4 & 14.6 & 13.5 \\
\hline & 5 & $0+7.4$ & 2.4 & 15.6 & 35.9 & 38.9 \\
\hline & 7 & $0+6.5$ & 0 & 5.7 & 36.8 & 51.0 \\
\hline \multirow{3}{*}{ P112 } & 3 & 100 & 0 & 0 & 0 & 0 \\
\hline & 5 & 100 & 0 & 0 & 0 & 0 \\
\hline & 7 & 100 & 0 & 0 & 0 & 0 \\
\hline \multirow{3}{*}{ PxS } & 3 & 100 & 0 & 0 & 0 & 0 \\
\hline & 5 & 100 & 0 & 0 & 0 & 0 \\
\hline & 7 & 100 & 0 & 0 & 0 & 0 \\
\hline \multirow{3}{*}{ PB8 } & 3 & 100 & 0 & 0 & 0 & 0 \\
\hline & 5 & 100 & 0 & 0 & 0 & 0 \\
\hline & 7 & 100 & 0 & 0 & 0 & 0 \\
\hline
\end{tabular}

The results presented in Table 1 demonstrate that among seven tested strains, three were able to convert the unsaturated lactone 1. StrainsPBo6S, PB63S, and PUSAS transformed lactone 1 into two products: Hydroxylactone 3 and epoxylactone 4 (Scheme 1).

The results in Table 2 show that the unsaturated lactone 2 was transformed into four different products. The PBo6S and PB63S strains converted this compound to hydroxylactone 5 and epoxyhydroxylactone 7. Additionally, when the PBo6S strain was used for biotransformation, the formation of epoxylactone 6 was observed. Two successive strains, i.e., PUSAS and PB7'96, transformed the substrate mainly to the already mentioned epoxy-hydroxylactone 7 and epoxy-hydroxylactone 8 (Scheme 2). 


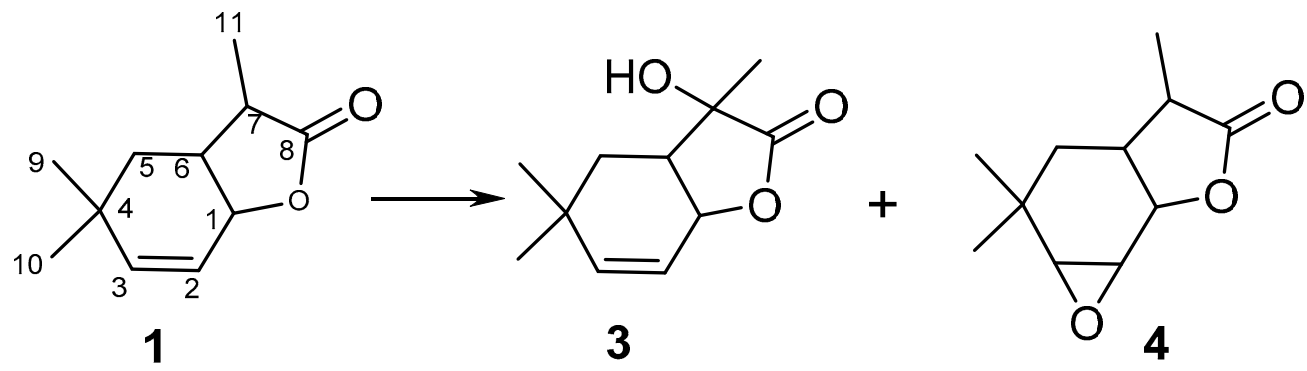

Scheme 1. The products obtained as a result of biotransformation of unsaturated lactone 1.<smiles>[Y]C1C(=O)OC2C=CC(C)(C)C[C@]2([Y])C1[Y]</smiles>

Scheme 2. The products obtained as a result of biotransformation of unsaturated lactone 2 .

For the next stage of the research, which included preparative biotransformations, strains capable of conducting transformations of substrates $\mathbf{1}$ and $\mathbf{2}$ with high efficiency were used. The results of the preparative scale biotransformation are described in Tables 3 and 4.

Table 3. Results of the preparative scale biotransformation of lactone $\mathbf{1}$ after $\mathbf{7}$ days of incubation (in \% according to GC).

\begin{tabular}{cccccc}
\hline Strain & Lactone 1 A + B (\%) & Lactone 3 (\%) & Isolated Yield (g/\%) & Lactone 4 (\%) & Isolated Yield (g/\%) \\
\hline PBo6S & $0+8.9$ & 41.0 & $0.0254 / 23.1$ & 50.1 & $0.0117 / 10.6$ \\
\hline
\end{tabular}

The unsaturated lactone 1 was subjected to a biotransformation with the PBo6S strain. It resulted in hydroxylactone 3, which was formed exclusively from the A-isomer, and epoxylactone 4 formed as a mixture of two isomers A and B. As a result of the chromatographic separation of the products, the pure B epoxylactone 4 isomer was partially isolated.

Table 4. Results of the preparative scale biotransformation of lactone 2 after 7 days of incubation (in \% according to GC).

\begin{tabular}{ccccccccc}
\hline $\begin{array}{c}\text { Lactone 2 } \\
\mathbf{A}+\mathbf{B}(\mathbf{\%})\end{array}$ & $\begin{array}{c}\text { Lactone 5 } \\
\mathbf{( \% )}\end{array}$ & $\begin{array}{c}\text { Isolated } \\
\text { Yield (g/\%) }\end{array}$ & $\begin{array}{c}\text { Lactone } \\
\mathbf{6} \mathbf{( \% )}\end{array}$ & $\begin{array}{c}\text { Isolated } \\
\text { Yield (g/\%) }\end{array}$ & $\begin{array}{c}\text { Lactone } \\
\mathbf{7 ~ ( \% )}\end{array}$ & $\begin{array}{c}\text { Isolated } \\
\text { Yield }(\mathbf{g} / \%)\end{array}$ & $\begin{array}{c}\text { Lactone } \\
\mathbf{8} \mathbf{( \% )}\end{array}$ & $\begin{array}{c}\text { Isolated } \\
\text { Yield }(\mathbf{g} / \%)\end{array}$ \\
\hline $0+12.0$ & 24.0 & $0.007 / 6.7$ & 16.6 & $0.005 / 4.9$ & 47.4 & $0.013 / 11.2$ & 0 & - \\
$0+26.3$ & 62.8 & $0.020 / 18.3$ & 0 & - & 10.9 & $0.008 / 6.5$ & 0 & - \\
$0+0$ & 9.0 & - & 8.5 & - & 28.3 & $0.010 / 9.0$ & 54.2 & $0.013 / 11.2$ \\
$0+6.5$ & 0 & - & 8.4 & - & 28.4 & $0.013 / 11.2$ & 56.7 & $0.012 / 9.9$ \\
\hline
\end{tabular}

The unsaturated lactone $\mathbf{2}$ was subjected to preparative biotransformations using four strains. As a result, four derivatives were obtained: Hydroxylactone 5, epoxylactone 6, and two epoxy-hydroxylactones 7 and $\mathbf{8}$. Lactones 5 and 7 were formed from the isomer $\mathrm{A}$, whereas the lactones 6 and 8 were from the B-isomer of the substrate.

In the next step, two parameters - optical purity and enantiospecificity-of lactones 3-6 and $\mathbf{8}$ were determined. These lactones were obtained as single isomers during preparative biotransformation; the results of this step are included in Table 5.

The results presented in Table 5 prove that the lactones of the three methyl groups, which are compounds 3 and 4, were characterized by high (above 80\%) enantiomeric excess. An additional 
methyl group significantly reduced the enantiomeric excess of products 5,6 , and 8 . The best results of $35.4 \%$ and $30.3 \%$ were obtained with epoxylactone 8 . All lactones were formed predominantly by the (-)-enantiomer. (Supplementary Materials, Figures S39-S43).

Table 5. The values of enantiospecificity and optical purity of hydroxylactones 3-6 and 8.

\begin{tabular}{cccc}
\hline Strain & Lactone & ee (\%) & {$[a]_{20}^{D}$} \\
\hline & $\mathbf{3}$ & 82.1 & $-13.263\left(\mathrm{C}=0.17, \mathrm{CHCl}_{3}\right)$ \\
PBo6S & $\mathbf{4}$ & 86.7 & $-13.423\left(\mathrm{C}=0.20, \mathrm{CHCl}_{3}\right)$ \\
& $\mathbf{5}$ & 22.6 & $-5.725\left(\mathrm{C}=0.20, \mathrm{CHCl}_{3}\right)$ \\
& $\mathbf{6}$ & 12.4 & $-3.385\left(\mathrm{C}=0.29, \mathrm{CHCl}_{3}\right)$ \\
\hline PB63S & $\mathbf{5}$ & 23.4 & $-5.836\left(\mathrm{C}=0.29, \mathrm{CHCl}_{3}\right)$ \\
PUSAS & $\mathbf{8}$ & 35.4 & $-10.839\left(\mathrm{C}=0.74, \mathrm{CHCl}_{3}\right)$ \\
PB7'96 & $\mathbf{8}$ & 30.3 & $-6.090\left(\mathrm{C}=0.42, \mathrm{CHCl}_{3}\right)$ \\
\hline
\end{tabular}

As mentioned in the introduction, hydroxylactones are often characterized by a variety of biological activities. Therefore, all biotransformation products were tested for antimicrobial activity against strains that are pathogens for plants or animals. There were Escherichia coli C1, Staphylococcus aureus, Candida albicans KL-1, Alternaria alternata, Fusarium linii A3, and Aspergillus niger XP. In order to compare the biological activity of substrates and biotransformation products, unsaturated lactones were also tested. The obtained results were presented as the mean \pm standard deviation (SD) of optical density $\Delta \mathrm{OD}$ values and are shown in Tables 6 and 7. (Supplementary Materials, Figures S44-S49).

Table 6. Antimicrobial activity of lactone 1 and its derivatives ( $\triangle \mathrm{OD}$ as the mean $\pm \mathrm{SD})$.

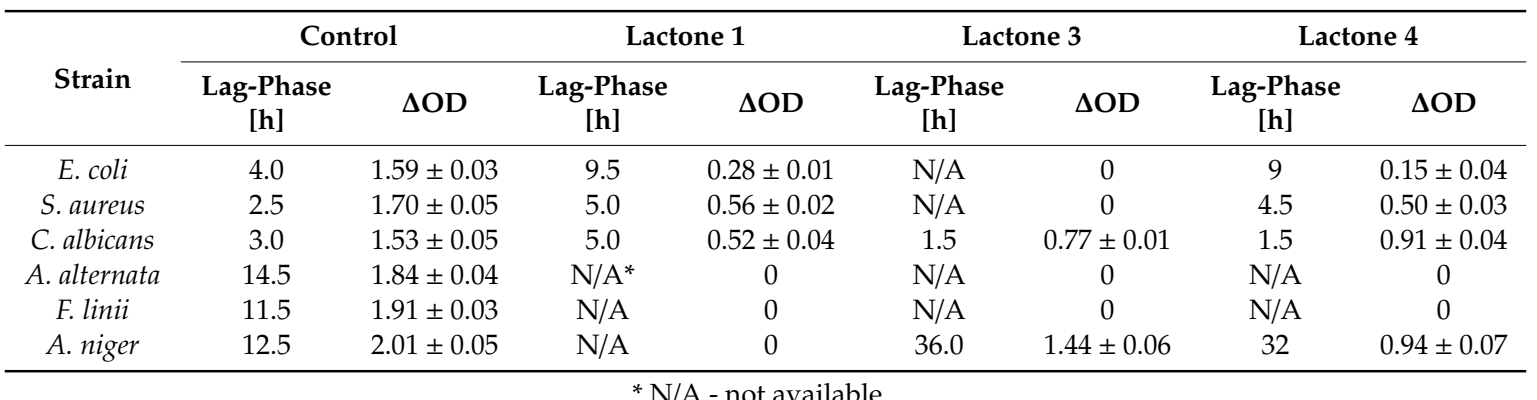

It can be noticed that the most active compound was hydroxylactone 3 . This compound completely inhibited the growth of four of the six tested strains, which included E. coli and $S$. aureus bacteria strains as well as filamentous fungi $A$. alternata and F. linii strains. In case of the $A$. niger strain, a three-fold increase in the lag-phase duration occurred. The unsaturated lactone $\mathbf{1}$ completely inhibited only the growth of strains of filamentous fungi. A similar effect was shown by epoxylactone 4 in relation to A. alternata and F. linii strains.

Table 7. Antimicrobial activity of lactone 2 and its derivatives ( $\triangle \mathrm{OD}$ as the mean $\pm \mathrm{SD})$.

\begin{tabular}{|c|c|c|c|c|c|c|c|c|c|c|c|c|}
\hline \multirow[b]{2}{*}{ Strain } & \multicolumn{2}{|c|}{ Control } & \multicolumn{2}{|c|}{ Lactone 2} & \multicolumn{2}{|c|}{ Lactone 5} & \multicolumn{2}{|c|}{ Lactone 6} & \multicolumn{2}{|c|}{ Lactone 7} & \multicolumn{2}{|c|}{ Lactone 8} \\
\hline & $\begin{array}{c}\text { Lag- } \\
\text { Phase } \\
{[\mathrm{h}]}\end{array}$ & $\Delta \mathrm{OD}$ & $\begin{array}{c}\text { Lag- } \\
\text { Phase } \\
{[\mathrm{h}]}\end{array}$ & $\Delta \mathrm{OD}$ & $\begin{array}{c}\text { Lag- } \\
\text { Phase } \\
{[\text { h] }}\end{array}$ & $\Delta \mathrm{OD}$ & $\begin{array}{c}\text { Lag- } \\
\text { Phase } \\
{[\mathrm{h}]}\end{array}$ & $\Delta \mathrm{OD}$ & $\begin{array}{c}\text { Lag- } \\
\text { Phase } \\
{[\text { h] }}\end{array}$ & $\Delta \mathrm{OD}$ & $\begin{array}{c}\text { Lag- } \\
\text { Phase } \\
{[\mathrm{h}]}\end{array}$ & $\Delta O D$ \\
\hline E. coli & 4.0 & $1.59 \pm 0.03$ & 11 & $0.11 \pm 0.03$ & 9.5 & $0.18 \pm 0.03$ & 12.5 & $0.25 \pm 0.05$ & 5 & $0.18 \pm 0.05$ & 6.5 & $0.28 \pm 0.03$ \\
\hline S. aureus & 2.5 & $1.70 \pm 0.05$ & 25.5 & 0.20 & 7.0 & $0.44 \pm 0.03$ & 3.0 & $0.56 \pm 0.05$ & 6.5 & $0.20 \pm 0.04$ & 5.5 & $0.50 \pm 0.03$ \\
\hline C. albicans & 3.0 & $1.53 \pm 0.05$ & 5.5 & 0.40 & 2.5 & $0.61 \pm 0.07$ & 1.0 & $0.91 \pm 0.01$ & 1.5 & $0.75 \pm 0.02$ & 1.0 & $0.92 \pm 0.03$ \\
\hline A. alternata & 14.5 & $1.84 \pm 0.04$ & N/A & 0 & N/A & 0 & N/A & 0 & N/A & 0 & N/A & 0 \\
\hline F. linii & 11.5 & $1.91 \pm 0.03$ & N/A & 0 & N/A & 0 & N/A & 0 & N/A & 0 & N/A & 0 \\
\hline A. niger & 12.5 & $2.01 \pm 0.05$ & 22.5 & $0.93 \pm 0.04$ & 42.5 & $0.67 \pm 0.03$ & 25.5 & $1.21 \pm 0.06$ & 23.5 & $1.24 \pm 0.02$ & 27.5 & $1.75 \pm 0.03$ \\
\hline
\end{tabular}


An analysis of the results indicates that the most sensitive to the tested compounds strains were filamentous fungi $A$. alternata and F. linii. The unsaturated lactone 2 as well as all its derivatives, lactones 5-8, completely inhibited the growth of these microorganisms. In the presence of the A. niger strain, the lag-phase duration increased significantly. A similar phenomenon was also observed in case of bacterial strains. Lag-phase elongation was caused by lactones 2, 5, and $\mathbf{6}$ in case of E. coli, and lactones $\mathbf{2}, \mathbf{5}$, and $\mathbf{7}$ in case of the $S$. aureus strain.

In the next stage, the values of Minimal Inhibitory Concentration (MIC) for compounds that completely inhibit the growth of tested strains was determined. Lactones 1, 3, and 4 were tested for E. coli, S. aureus, A. alternate, and F. linii strains, and lactones 2 and 5-8-for A. alternata and F. linii strains. The study was conducted for concentrations of 0.0075 to $0.1 \mathrm{mg} / \mathrm{mL}$. The obtained results are presented in Table 8 .

Table 8. The Minimal Inhibitory Concentration MIC values of lactones 1-8.

\begin{tabular}{|c|c|c|c|c|c|c|c|c|}
\hline Strain & Lactone 1 & Lactone 2 & Lactone 3 & Lactone 4 & Lactone 5 & Lactone 6 & Lactone 7 & Lactone 8 \\
\hline & \multicolumn{8}{|c|}{$[\mathrm{mg} / \mathrm{mL}]$} \\
\hline E. coli & nt & nt & 0.1 & nt & $\mathrm{nt}$ & nt & $\mathrm{nt}$ & nt \\
\hline S. aureus & nt & nt & 0.1 & nt & nt & nt & nt & nt \\
\hline A. alternata & 0.05 & 0.05 & 0.05 & 0.05 & 0.05 & 0.1 & 0.1 & 0.1 \\
\hline F. linii & 0.05 & 0.05 & 0.05 & 0.05 & 0.025 & 0.05 & 0.1 & 0.05 \\
\hline A. niger & 0.1 & nt & nt & nt & nt & nt & nt & nt \\
\hline
\end{tabular}

The best result was noted for lactone 5 , which completely inhibited the growth of the F. linii strain at $0.025 \mathrm{mg} / \mathrm{mL}$. Lactones $\mathbf{1} \mathbf{- 5}$ were able to inhibit the growth of $A$. alternata strains at a concentration of $0.05 \mathrm{mg} / \mathrm{mL}$. Lactones $\mathbf{1 - 4}, \mathbf{6}$, and $\mathbf{8}$ inhibited the growth of the $F$. linii strain also at a concentration of $0.05 \mathrm{mg} / \mathrm{mL}$.

\section{Discussion}

Two known unsaturated lactones $\mathbf{1}$ and $\mathbf{2}$ were used for the tests. Each of these compounds formed as a mixture of two diastereoisomers (A and B) (Supplementary Materials, Figures S1-S4). In case of compound 1, the difference concerned the spatial orientation of the methyl group at the C-7 carbon. This group was located on the same plane as the lactone ring (1A) or across this plane (1B). In case of compound 2, larger differences were observed. For the 2A-isomer, the C-O bond of the lactone ring was in the axial position, while the $\mathrm{CH}_{3}-11$ group was located across the plane of the lactone ring. In case of the $2 \mathrm{~B}$ isomer, the $\mathrm{C}-\mathrm{O}$ bond of the lactone ring was in the equatorial position, while the $\mathrm{CH}_{3}-11$ group was located in the plane of the lactone ring (Figure 2).

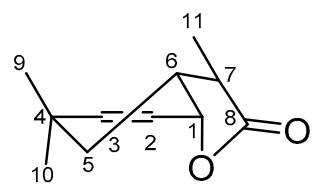

$1 \mathrm{~A}$

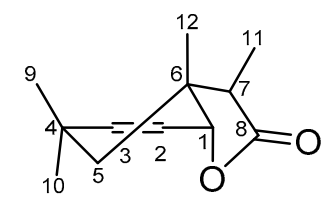

$2 A$

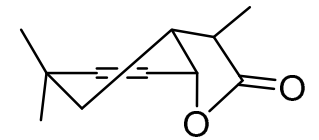

1B

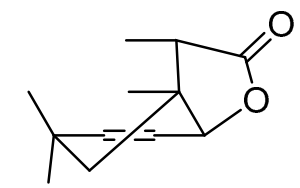

2B

Figure 2. Spatial structures of stereoisomers (A) and (B) of unsaturated lactones $\mathbf{1}$ and $\mathbf{2}$.

As a result of the biotransformations, a number of compounds were obtained: Two hydroxylactones 2 and 5 , two epoxylactones 3 and 6 , and two epoxy-hydroxy lactones 7 and 8 . 
Analysis of the ${ }^{1} \mathrm{H}$ NMR spectra showed that hydroxylactone 3 and epoxy-hydroxylactones 7 and $\mathbf{8}$ are novel compounds. The remaining products were identical to those obtained earlier as a result of biotransformation carried out with filamentous fungi. Epoxylactone 4 was obtained from substrate 1 using the Absidia cylindrospora AM336 strain. Hydroxylactone 5 was obtained from substrate 2 using Syncephalastrum racemosum AM105 and Absidia cylindrospora AM336 strains, while epoxylactone 6 was from the Penicilium vermiculatum AM30 strain [31]. It is worth noting that as a result of the biotransformations carried out using filamentous fungi, hydroxylactone $\mathbf{5}$ was obtained as a mixture of both isomers A and B. However, by using fungi of the Pleurotus genus, the lactone $\mathbf{5}$ was obtained only from the A-isomer. Since the structure of the known biotransformation products have been described previously [31], here, a detailed analysis of the ${ }^{1} \mathrm{H}$ NMR spectra of the new compounds (3, 7, and 8) is presented.

In case of substrate $\mathbf{1}$, hydroxylactone 3 was the new product. This compound was formed by hydroxylation of the C-7 tertiary carbon, as evidenced by the lack of signal from the proton H-7. A comparison of the ${ }^{1} \mathrm{H}$ NMR spectra of both the substrate A and B isomers, in particular the chemical shifts of protons $\mathrm{H}-1, \mathrm{H}-6$, and the group, $\mathrm{CH}_{3}-11$, allowed the statement that lactone 3 formed by hydroxylation of the isomer A.

As a result of the biotransformation of substrate 2, two new compounds-epoxy-hydroxylactones 7 and 8-were obtained. By analyzing the results obtained from the course of the screening biotransformation, it was found that compound 7 formed as a result of epoxidation of hydroxylactone 3 , and compound 8 by hydroxylation of epoxylactone 6 . This statement was also confirmed by analysis of the ${ }^{1} \mathrm{H}$ NMR spectra of biotransformation products. In case of lactones 5 and 7 , the differences occurring in the chemical shifts of protons $\mathrm{H}-1, \mathrm{H}-2, \mathrm{H}-3$, and the $\mathrm{CH}_{2}-5$ group can be noticed. This change is mainly affected by the chemical protons $\mathrm{H}-2$ and $\mathrm{H}-3$, for which the mentioned values changed from 5.76 and 5.86 ppm (5) to 2.96 and $3.58 \mathrm{ppm}$ (7), respectively. This change indicates epoxidation of the double bond in the existing hydroxylactone. Epoxidation is also confirmed by the observed shift of the signal coming from the H-1 proton from 4.62 (5) to $4.77 \mathrm{ppm}$ (7). However, when considering the spectroscopic data on compound 8 , it can be seen that its spectrum is very similar to the spectrum of epoxylactone 6 . The only difference relates to the shift of the signal derived from the methyl group, $\mathrm{CH}_{3}-10$, from 1.10 (6) to $3.48 \mathrm{ppm}$ (8) and the change in the multiplicity of this signal from the singlet to the doublet of the doublet. This means that in the already existing epoxylactone, the $\mathrm{CH}_{3}-10$ group was hydroxylated.

Biotransformations of the unsaturated compounds described in the literature using fungi of the Pleurotus genus are mainly based on hydroxylation in the allylic position [15-18]. In our case, this type of reaction was not observed. Products were formed by hydroxylation of a tertiary carbon or double bond epoxidation. Such reactions are rather characteristic of filamentous fungi [28-31]. The formation of epoxy-hydroxylactones was also very interesting. Such compounds have not been observed by us so far. Their formation indicates that Pleurotus ostreatus are characterized by a completely different metabolism than the previously used filamentous fungi.

Studies carried out to determine the antimicrobial activity of substrates and biotransformation products gave very interesting results. The unsaturated lactone 1 completely inhibited the growth of tested strains of filamentous fungi (A. alternata, F. linii, A. niger). In case of bacterial and yeast strains, partial inhibition of growth and an approximately two-fold increase in the lag-phase duration was observed. The introduction of a hydroxy group to the lactone ring resulted in an increase in the ability to inhibit the growth of microorganisms by compound 3 . Four of the six tested strains were found to be sensitive to this lactone. In turn, epoxidation of the double bond negatively influenced the degree of inhibition of the growth of the studied microorganisms.

In case of unsaturated lactone 2 and its derivatives, no relationship was observed between the structure of the compound and its ability to inhibit or limit the growth of the tested microorganisms. All compounds were able to completely inhibit the growth of only two strains: A. alternata and $F$. linii strains. In other tested strains, partial inhibition of growth and prolongation of the lag-phase duration was observed. 
Compounds capable of completely inhibiting the growth of microorganisms were tested for determination of the MIC. The most effective of these was hydroxylactone 5, already active at 0.025 $\mathrm{mg} / \mathrm{mL}$, against the $F$. linii strain. Of the remaining lactones, the majority showed activity at a concentration of $0.05 \mathrm{mg} / \mathrm{mL}$ against $A$. alternata (compounds 1-5) and F. linii (compounds 1-4, 6, 8) strains.

\section{Materials and Methods}

\subsection{General Methods}

The products obtained during biotransformation were purified using preparative column chromatography. Silica gel (Kieselgel 60, 230-400 mesh, Merck, Darmstadt, Germany) was used as the adsorbent. The mixture of hexane and acetone in a volume ratio of 3:1 was used as an eluent. The purity of all compounds and progress of biotransformation was checked by gas chromatography GC analysis carried out on an Agilent Technologies 6890N instrument (Agilent Technologies, Santa Clara, CA, USA) using a DB-5HT column (cross-linked methyl silicone gum, $30 \mathrm{~m} \times 0.32 \mathrm{~mm} \times 0.25 \mu \mathrm{m}$ ). The conditions were as follows: Injector $150{ }^{\circ} \mathrm{C}$, detector (FID) $300^{\circ} \mathrm{C}$, column temperature $100{ }^{\circ} \mathrm{C}$, ramp $100-240{ }^{\circ} \mathrm{C}$ at a rate of $25^{\circ} \mathrm{C} / \mathrm{min}$, ramp $240-300^{\circ} \mathrm{C}$ at a rate of $40^{\circ} \mathrm{C} / \mathrm{min}$. The enantiomeric excesses of the products of biotransformation were determined by Agilent Technologies $6890 \mathrm{~N}$ GC analysis using the chiral column CP-Chirasil-DEX B-325 $(25 \mathrm{~m} \times 0.25 \mathrm{~mm} \times 0.25 \mu \mathrm{m}$, Supelco, Bellefonte, PA, USA), injector $200{ }^{\circ} \mathrm{C}$, detector (FID) $200^{\circ} \mathrm{C}$, initial column temperature $130{ }^{\circ} \mathrm{C}$, ramp $130-160^{\circ} \mathrm{C}$ at a rate of $2{ }^{\circ} \mathrm{C} / \mathrm{min}$, ramp $160-200{ }^{\circ} \mathrm{C}$ at a rate of $10{ }^{\circ} \mathrm{C} / \mathrm{min}$ and hold $1 \mathrm{~min}$ at $200^{\circ} \mathrm{C}$ (for compounds $4, \mathbf{6}$, 8). For compounds 3 and 5, enantiomeric excesses were determined by a Varian CP3380 instrument using the chiral column Gamma DEX $325(30 \mathrm{~m} \times 0.25 \mathrm{~mm} \times 0.25 \mu \mathrm{m}$, Supelco, Bellefonte, PA, USA), injector $150^{\circ} \mathrm{C}$, detector (FID) $200^{\circ} \mathrm{C}$, initial column temperature $130{ }^{\circ} \mathrm{C}$, ramp $130-160^{\circ} \mathrm{C}$ at a rate of $0.7^{\circ} \mathrm{C} / \mathrm{min}$, ramp and $160-200^{\circ} \mathrm{C}$ at a rate of $20^{\circ} \mathrm{C} / \mathrm{min}$. High resolution mass spectrometry analysis using a Waters LCT Premier XE instrument (ESI ionization, Waters, Milford, MA, USA) was used for confirmation of the molar masses of the obtained compounds. ${ }^{1} \mathrm{H}$ NMR and ${ }^{13} \mathrm{C}$ NMR spectra were recorded in a $\mathrm{CDCl}_{3}$ solution on a JEOL DeltaTM $400 \mathrm{MHz}$ spectrometer (JEOL USA, Inc., Peabody, MA, USA). Jasco P-2000 polarimeter (Jasco, Easton, PA, USA) was used to determined optical rotations. Tested compounds were dissolved in chloroform, and their concentration was denoted in $\mathrm{g} / 100 \mathrm{~mL}$. Boetius apparatus was used to determine the melting points.

\subsection{Organic Synthesis}

The NMR spectra of two known unsaturated lactones $\mathbf{1}$ and $\mathbf{2}$ were obtained according to the procedure described in our earlier article [31]. Their NMR spectra are described below:

4,4,7-trimethyl-9-oxabicyclo[4.3.0]non-2-en-8-one (1). ${ }^{1} \mathrm{H} \mathrm{NMR}\left(400 \mathrm{MHz}, \mathrm{CDCl}_{3}\right)$ : 5.86-5.91 (m, 2H, $\mathrm{H}-3 \mathrm{~A}, \mathrm{H}-3 \mathrm{~B}), 5.74-5.80(\mathrm{~m}, 2 \mathrm{H}, \mathrm{H}-2 \mathrm{~A}, \mathrm{H}-2 \mathrm{~B}), 4.78(\mathrm{dd}, \mathrm{J}=5.2$ and $4.8 \mathrm{~Hz}, 1 \mathrm{H}, \mathrm{H}-1 \mathrm{~A}), 4.59(\mathrm{t}, \mathrm{J}=4.8 \mathrm{~Hz}$, 1H, H-1B), 2.93 (quintet, J = 7.6 Hz, 1H, H-7B), 2.60-2.66 (m, 1H, H-6B), 2.41 (q, J = 7.6 Hz, 1H, H-7A), 2.24-2.30 (m, 1H, H-6A), $1.52\left(\mathrm{dd}, \mathrm{J}=13.6\right.$ and $5.2 \mathrm{~Hz}, 1 \mathrm{H}$, one of $\left.\mathrm{CH}_{2}-5 \mathrm{~A}\right), 1.42(\mathrm{dd}, \mathrm{J}=13.2$ and $4.4 \mathrm{~Hz}$, $1 \mathrm{H}$, one of $\left.\mathrm{CH}_{2}-5 \mathrm{~B}\right), 1.35\left(\mathrm{~d}, \mathrm{~J}=7.6 \mathrm{~Hz}, 3 \mathrm{H}, \mathrm{CH}_{3}-11 \mathrm{~A}\right), 1.20-1.33\left(\mathrm{~m}, 1 \mathrm{H}\right.$, one of $\left.\mathrm{CH}_{2}-5 \mathrm{~A}\right), 1.18(\mathrm{~d}, \mathrm{~J}=$ $\left.7.2 \mathrm{~Hz}, 3 \mathrm{H}, \mathrm{CH}_{3}-11 \mathrm{~B}\right), 1.04-1.11\left(\mathrm{~m}, 1 \mathrm{H}\right.$, one of $\left.\mathrm{CH}_{2}-5 \mathrm{~B}\right), 1.04\left(\mathrm{~s}, 3 \mathrm{H}, \mathrm{CH}_{3}-10 \mathrm{~B}\right), 1.03\left(\mathrm{~s}, 3 \mathrm{H}, \mathrm{CH}_{3}-10 \mathrm{~A}\right)$, 0.99 (s, 3H, CH $\left.\mathrm{CH}_{3}-9 \mathrm{~B}\right), 0.98$ (s, 3H, $\left.\mathrm{CH}_{3}-9 \mathrm{~A}\right),{ }^{13} \mathrm{C} \mathrm{NMR}\left(100 \mathrm{MHz}, \mathrm{CDCl}_{3}\right)$ : 179.82 (C-8B), 178.91 (C-8A), 145.38 (C-3B), 144.89 (C-3A), 119.91 (C-2A), 119.76 (C-2B), 73.30 (C-1A), 73.20 (C-1B), 43.24 (C-7A), 40.12 (C-7B), 38.65 (C-6A), 38.48 (C-6B), 35.35 (C-5A), 33.59 (C-5B), 32.00 (C-4B), 31.85 (C-4A), 30.56 (C-10B), 30.21 (C-10A), 27.28 (C-9A), 26.83 (C-9B), 15.61 (C-11A), 9.22 (C-11B).

4,4,6,7-trimethyl-9-oxabicyclo[4.3.0]non-2-en-8-one (2). ${ }^{1} \mathrm{H} \mathrm{NMR}\left(400 \mathrm{MHz}, \mathrm{CDCl}_{3}\right): 5.87(\mathrm{~d}, \mathrm{~J}=$ $10.0 \mathrm{~Hz}, 1 \mathrm{H}, \mathrm{H}-3 \mathrm{~B}), 5.75(\mathrm{dd}, \mathrm{J}=10.0$ and $5.2 \mathrm{~Hz}, 1 \mathrm{H}, \mathrm{H}-2 \mathrm{~B}), 5.66(\mathrm{~d}, \mathrm{~J}=10.4 \mathrm{~Hz}, 1 \mathrm{H}, \mathrm{H}-3 \mathrm{~A}), 5.53$ (dd, J $=10.4$ and $2.8 \mathrm{~Hz}, 1 \mathrm{H}, \mathrm{H}-2 \mathrm{~A}), 4.47(\mathrm{~s}, 1 \mathrm{H}, \mathrm{H}-1 \mathrm{~A}), 4.25(\mathrm{~d}, \mathrm{~J}=5.2 \mathrm{~Hz}, 1 \mathrm{H}, \mathrm{H}-1 \mathrm{~B}), 2.75(\mathrm{q}, \mathrm{J}=7.2 \mathrm{~Hz}, 1 \mathrm{H}$, $\mathrm{H}-7 \mathrm{~A}), 2.41(\mathrm{q}, \mathrm{J}=7.2 \mathrm{~Hz}, 1 \mathrm{H}, \mathrm{H}-7 \mathrm{~B}), 1.67\left(\mathrm{~d}, \mathrm{~J}=15.2,1 \mathrm{H}\right.$, one of $\left.\mathrm{CH}_{2}-5 \mathrm{~A}\right), 1.67(\mathrm{~d}, \mathrm{~J}=15.2 \mathrm{~Hz}, 1 \mathrm{H}$, one of $\left.\mathrm{CH}_{2}-5 \mathrm{~A}\right), 1.44\left(\mathrm{~d}, \mathrm{~J}=15.2 \mathrm{~Hz}, 1 \mathrm{H}\right.$, one of $\left.\mathrm{CH}_{2}-5 \mathrm{~A}\right), 1.23\left(\mathrm{~d}, \mathrm{~J}=14.0 \mathrm{~Hz}, 2 \mathrm{H}, \mathrm{CH}_{2}-5 \mathrm{~B}\right), 1.21(\mathrm{~s}, 3 \mathrm{H}$, 
$\left.\mathrm{CH}_{3}-12 \mathrm{~B}\right), 1.11\left(\mathrm{~d}, \mathrm{~J}=7.2 \mathrm{~Hz}, 3 \mathrm{H}, \mathrm{CH}_{3}-11 \mathrm{~B}\right), 1.09\left(\mathrm{~s}, 3 \mathrm{H}, \mathrm{CH}_{3}-10 \mathrm{~B}\right), 1.07\left(\mathrm{~d}, \mathrm{~J}=6.4 \mathrm{~Hz}, 3 \mathrm{H}, \mathrm{CH}_{3}-11 \mathrm{~A}\right)$, $1.07\left(\mathrm{~s}, 3 \mathrm{H}, \mathrm{CH}_{3}-12 \mathrm{~A}\right), 1.02\left(\mathrm{~s}, 3 \mathrm{H}, \mathrm{CH}_{3}-10 \mathrm{~A}\right), 1.02\left(\mathrm{~s}, 3 \mathrm{H}, \mathrm{CH}_{3}-9 \mathrm{~B}\right), 0.99\left(\mathrm{~s}, 3 \mathrm{H}, \mathrm{CH}_{3}-9 \mathrm{~A}\right),{ }^{13} \mathrm{C} \mathrm{NMR}$ $\left(100 \mathrm{MHz}, \mathrm{CDCl}_{3}\right): 179.00$ (C-8A), $178.59(\mathrm{C}-8 \mathrm{~B}), 144.75$ (C-3B), 140.65 (C-3A), 120.67 (C-2A), 117.64 (C-2B), 81.03 (C-1A), 78.41 (C-1B), 49.98 (C-7B), 42.42 (C-5A), 41.16 (C-7A), 40.51 (C-4A), 40.31 (C-4B), 38.39 (C-5B), 33.17 (C-10A), 33.05 (C-9B), 31.85 (C-6B), 31.59 (C-6A), 29.52 (C-12A), 28.51 (C-10B), 23.13 (C-12B), 22.95 (C-9A), 7.70 (C-11A), 7.31 (C-11B).

\subsection{Biotransformation}

\subsubsection{Microorganisms}

The whole cells of seven strains of oyster mushroom (Pleurotus ostreatus (Jacq.) P. Kumm) were obtained from the collection of Department of Fruit, Vegetable and Mushroom Technology at the University of Life Sciences in Lublin. The isolates were from Poland (PB63S, PBo6S, PxS, P112), Japan (PB8, PB7'96), and the USA (PUSAS). All strains are available in the collection stored in Department of Plant Protection, Wroclaw University of Environmental and Life Sciences. All these strains were cultivated on PDA (Potato Dextrose Agar) medium and stored in refrigerator at $4{ }^{\circ} \mathrm{C}$.

\subsubsection{Screening Procedure}

Tested strains were grown in $300 \mathrm{~mL}$ Erlenmeyer flasks containing $100 \mathrm{~mL}$ of medium composed of $3 \%$ glucose and $1 \%$ peptone dissolved in distilled water. After 5 days, $10 \mathrm{mg}$ of the substrate dissolved in $1 \mathrm{~mL}$ of acetone was added to the growing mycelium. After 3, 5, and 7 days, one third of the contents of the flask was removed, and the whole was extracted with methylene chloride $(15 \mathrm{~mL})$ and analyzed on GC (DB-17 column).

\subsubsection{Preparative Biotransformation}

Preparative biotransformations were carried out analogously to screening biotransformations, the difference being that 10 Erlenmeyer flasks with a capacity of $300 \mathrm{~mL}$ were used. To each flask with growing mycelium, $10 \mathrm{mg}$ of substrate was added (total of $100 \mathrm{mg}$ ). After 7 days, the whole was extracted with methylene chloride $(3 \times 40 \mathrm{~mL})$. The combined organic fractions were dried over $\mathrm{MgSO}_{4}$, and then the solvent was evaporated. The obtained products were purified on a chromatography column (silica gel, hexane: acetone 3:1). As a result of the biotransformation carried out, six products were obtained, whose physicochemical data (for new compounds) and spectral (for all compounds) are listed below.

7-Hydroxy-4,4,7-trimethyl-9-oxabicyclo[4.3.0]non-2-en-8-one (3). White solid, m.p. $=72-73{ }^{\circ} \mathrm{C},{ }^{1} \mathrm{H}$ NMR $\left(400 \mathrm{MHz}, \mathrm{CDCl}_{3}\right): 5.94(\mathrm{~d}, \mathrm{~J}=10.0 \mathrm{~Hz}, 1 \mathrm{H}, \mathrm{H}-3), 5.83(\mathrm{dd}, \mathrm{J}=10.0$ and $4.8 \mathrm{~Hz}, 1 \mathrm{H}, \mathrm{H}-2), 5.00(\mathrm{dd}$, $\mathrm{J}=4.8$ and $4.0 \mathrm{~Hz}, 1 \mathrm{H}, \mathrm{H}-1), 2.47(\mathrm{dt}, \mathrm{J}=14.4$ and $4.8 \mathrm{~Hz}, 1 \mathrm{H}, \mathrm{H}-6), 1.41(\mathrm{dd}, \mathrm{J}=14.4$ and $4.8 \mathrm{~Hz}, 1 \mathrm{H}$, one of $\left.\mathrm{CH}_{2}-5\right), 1.41\left(\mathrm{~s}, 3 \mathrm{H}, \mathrm{CH}_{3}-11\right), 1.05\left(\mathrm{~s}, 3 \mathrm{H}, \mathrm{CH}_{3}-10\right), 1.00\left(\mathrm{~s}, 3 \mathrm{H}, \mathrm{CH}_{3}-9\right), 0.86\left(\mathrm{~m}, 1 \mathrm{H}\right.$, one of $\left.\mathrm{CH}_{2}-5\right)$, ${ }^{13} \mathrm{C} \mathrm{NMR}\left(100 \mathrm{MHz}, \mathrm{CDCl}_{3}\right)$ : 177.14 (C-8), 145.21 (C-3), 119.63 (C-2), 34.05 (C-7), 73.01 (C-1), 42.07 (C-6), 34.05 (C-5), 32.13 (C-4), 30.38 (C-10), 26.80 (C-9), 19.27 (C-11), ESIHRMS: calcd for $\mathrm{C}_{11} \mathrm{H}_{16} \mathrm{O}_{3} \mathrm{Na}, \mathrm{m} / \mathrm{z}$ 219.0997 $(\mathrm{M}+\mathrm{H})^{+}$, found 219.1004. (Supplementary Materials, Figures S5-S10).

2,3-Epoxy-4,4,7-trimethyl-9-oxabicyclo[4.3.0]nonan-8-one (4). ${ }^{1} \mathrm{H} \mathrm{NMR}\left(400 \mathrm{MHz}, \mathrm{CDCl}_{3}\right): 4.78$ (d, J $=5.6 \mathrm{~Hz}, 1 \mathrm{H}, \mathrm{H}-1 \mathrm{~A}), 4.63(\mathrm{dd}, \mathrm{J}=4.4$ and $1.2 \mathrm{~Hz}, 1 \mathrm{H}, \mathrm{H}-1 \mathrm{~B}), 3.52(\mathrm{dd}, \mathrm{J}=3.6$ and $1.2 \mathrm{~Hz}, 1 \mathrm{H}, \mathrm{H}-2 \mathrm{~B})$, $3.42(\mathrm{dd}, \mathrm{J}=3.2$ and $1.2 \mathrm{~Hz}, 1 \mathrm{H}, \mathrm{H}-2 \mathrm{~A}), 3.00(\mathrm{~d}, \mathrm{~J}=3.6 \mathrm{~Hz}, 1 \mathrm{H}, \mathrm{H}-3 \mathrm{~B}), 2.98(\mathrm{~d}, \mathrm{~J}=3.6 \mathrm{~Hz}, 1 \mathrm{H}, \mathrm{H}-3 \mathrm{~A})$, 2.80 (quintet, $\mathrm{J}=7.2 \mathrm{~Hz}, 1 \mathrm{H}, \mathrm{H}-7 \mathrm{~B}), 2.34-2.43$ (m, 2H, H-6B and H-7A), 2.10-2.16 (m, 1H, H-6A), 1.27 $\left(\mathrm{d}, \mathrm{J}=7.6 \mathrm{~Hz}, 3 \mathrm{H}, \mathrm{CH}_{3}-11 \mathrm{~A}\right), 1.14-1.18\left(\mathrm{~m}, 2 \mathrm{H}, \mathrm{CH}_{2}-5 \mathrm{~A}\right), 1.12-1.14\left(\mathrm{~m}, 1 \mathrm{H}\right.$, one of $\left.\mathrm{CH}_{2}-5 \mathrm{~B}\right), 1.12(\mathrm{~s}$, $\left.6 \mathrm{H}, \mathrm{CH}_{3}-10 \mathrm{~A}, \mathrm{CH}_{3}-10 \mathrm{~B}\right), 1.11$ (d, J = 7.2 Hz, 3H, $\left.\mathrm{CH}_{3}-11 \mathrm{~B}\right), 1.03$ (s, 3H, $\left.\mathrm{CH}_{3}-9 \mathrm{~A}\right), 0.99$ (s, 3H, $\left.\mathrm{CH}_{3}-9 \mathrm{~B}\right)$, $0.81\left(\mathrm{dd}, \mathrm{J}=14.0\right.$ and $13.2 \mathrm{~Hz}, 1 \mathrm{H}$, one of $\left.\mathrm{CH}_{2}-5 \mathrm{~B}\right),{ }^{13} \mathrm{C} \mathrm{NMR}\left(100 \mathrm{MHz}, \mathrm{CDCl}_{3}\right): 179.08(\mathrm{C}-8 \mathrm{~B}), 179.08$ (C-8A), 74.18 (C-1A), 73.56 (C-B), 61.25 (C-3A), 61.17 (C-3B), 52.49 (C-2B), 52.31 (C-2A), 41.47 (C-7B), 39.99 (C-7A), 37.63 (C-6B), 35.79 (C-5B), 34.43 (C-6A), 33.23 (C-5A), 30.05 (C-10A), 28.83 (C-10B), 28.34 
(C-4B), 26.84 (C-4A), 25.43 (C-9B), 23.46 (C-9A), 14.49 (C-11B), 9.29 (C-11A). (Supplementary Materials, Figures S11-S18).

7-Hydroxy-4,4,6,7-tetramethyl-9-oxabicyclo[4.3.0]non-2-en-8-one (5). ${ }^{1} \mathrm{H}$ NMR (400 MHz, $\left.\mathrm{CDCl}_{3}\right)$ : $5.86(\mathrm{~d}, \mathrm{~J}=10.4 \mathrm{~Hz}, 1 \mathrm{H}, \mathrm{H}-3), 5.76(\mathrm{dd}, \mathrm{J}=10.4$ and $5.6 \mathrm{~Hz}, 1 \mathrm{H}, \mathrm{H}-2), 4.62(\mathrm{~d}, \mathrm{~J}=5.2 \mathrm{~Hz}, 1 \mathrm{H}, \mathrm{H}-1)$, 1.24-1.32 (m, $1 \mathrm{H}$, one of $\left.\mathrm{CH}_{2}-5\right), 1.28\left(\mathrm{~s}, 3 \mathrm{H}, \mathrm{CH}_{3}-12\right), 1.14\left(\mathrm{~s}, 3 \mathrm{H}, \mathrm{CH}_{3}-11\right), 1.12\left(\mathrm{~s}, 3 \mathrm{H}, \mathrm{CH}_{3}-10\right), 1.11-1.14$ (m, $1 \mathrm{H}$, one of $\left.\mathrm{CH}_{2}-5\right), 1.01\left(\mathrm{~s}, 3 \mathrm{H}, \mathrm{CH}_{3}-9\right),{ }^{13} \mathrm{C} \mathrm{NMR}\left(100 \mathrm{MHz}, \mathrm{CDCl}_{3}\right): 177.75(\mathrm{C}-8 \mathrm{~B}), 144.45(\mathrm{C}-3)$, 117.48 (C-2), 78.46 (C-1), 43.06 (C-7), 40.02 (C-5), 33.28 (C-10), 32.32 (C-6), 28.90 (C-9), 29.74 (C-4), 17.07 (C-12), 14.71 (C-11). (Supplementary Materials, Figures S19-S22).

2,3-Epoxy-4,4,6,7-tetramethyl-9-oxabicyclo[4.3.0]nonan-8-one (6). ${ }^{1} \mathrm{H} \mathrm{NMR}\left(400 \mathrm{MHz}, \mathrm{CDCl}_{3}\right): 4.23$ (s, 1H, H-1), 3.27 (d, J = 3.6 Hz, 1H, H-2), 2.93 (d, J = 3.2 Hz, 1H, H-3), 2.75 (q, J = 7.2 Hz, 1H, H-7), 1.32 $\left(\mathrm{d}, \mathrm{J}=15.2 \mathrm{~Hz}, 1 \mathrm{H}\right.$, one of $\left.\mathrm{CH}_{2}-5\right), 1.23\left(\mathrm{~d}, \mathrm{~J}=15.2 \mathrm{~Hz}, 1 \mathrm{H}\right.$, one of $\left.\mathrm{CH}_{2}-5\right), 1.16\left(\mathrm{~s}, 3 \mathrm{H}, \mathrm{CH}_{3}-12\right), 1.10(\mathrm{~s}$, $\left.3 \mathrm{H}, \mathrm{CH}_{3}-10\right), 1.05$ (d, J = 7.2 Hz, 3H, CH-11$), 0.93\left(\mathrm{~s}, 3 \mathrm{H}, \mathrm{CH}_{3}-9\right),{ }^{13} \mathrm{C} \mathrm{NMR}\left(100 \mathrm{MHz}, \mathrm{CDCl}_{3}\right): 178.28$ (C-8), 79.32 (C-1), 60.62 (C-3), 53.81 (C-2), 40.04 (C-4), 39.66 (C-7), 38.18 (C-5), 330.15 (C-6), 29.52 (C-10), 26.59 (C-12), 23.66 (C-11), 7.44 (C-9). (Supplementary Materials, Figures S23-S26).

2,3-Epoxy-7-hydroxy-4,4,6,7-tetramethyl-9-oxabicyclo[4.3.0]nonan-8-one (7). White solid, m.p. = 109-110 ${ }^{\circ} \mathrm{C},{ }^{1} \mathrm{H}$ NMR (400 MHz, $\left.\mathrm{CDCl}_{3}\right): 4.77$ (s, $\left.1 \mathrm{H}, \mathrm{H}-1\right), 3.58(\mathrm{dd}, \mathrm{J}=3.6$ and $2.4 \mathrm{~Hz}, 1 \mathrm{H}, \mathrm{H}-2), 2.96$ $(\mathrm{dd}, \mathrm{J}=3.6$ and $1.2 \mathrm{~Hz}, 1 \mathrm{H}, \mathrm{H}-3), 1.22\left(\mathrm{~s}, 3 \mathrm{H}, \mathrm{CH}_{3}-11\right), 1.21\left(\mathrm{~s}, 3 \mathrm{H}, \mathrm{CH}_{3}-12\right), 1.20\left(\mathrm{~s}, 3 \mathrm{H}, \mathrm{CH}_{3}-10\right), 1.07$ (s, $\left.3 \mathrm{H}, \mathrm{CH}_{3}-9\right), 1.04\left(\mathrm{~d}, \mathrm{~J}=14.0 \mathrm{~Hz}, 1 \mathrm{H}\right.$, one of $\left.\mathrm{CH}_{2}-5\right), 0.80\left(\mathrm{~d}, \mathrm{~J}=14.0 \mathrm{~Hz}, 1 \mathrm{H}\right.$, one of $\left.\mathrm{CH}_{2}-5\right),{ }^{13} \mathrm{C} \mathrm{NMR}$ (100 MHz, CDCl $)_{3}$ : 176.73 (C-8), 78.59 (C-1), 77.25 (C-7), 60.26 (C-3), 53.34 (C-2), 43.96 (C-6), 39.53 (C-5), 31.60 (C-9), 29.03 (C-4), 26.97 (C-12), 16.71 (C-10), 15.08 (C-11), ESIHRMS: calcd for $\mathrm{C}_{11} \mathrm{H}_{18} \mathrm{O}_{4} \mathrm{Na}, \mathrm{m} / \mathrm{z}$ 249.1103 $(\mathrm{M}+\mathrm{H})^{+}$, found 249.1105. (Supplementary Materials, Figures S27-S32).

2,3-Epoxy-10-hydroxy-4,4,6,7-tetramethyl-9-oxabicyclo[4.3.0]nonan-8-one (8). White solid, m.p. = 107-108 ${ }^{\circ} \mathrm{C},{ }^{1} \mathrm{H}$ NMR $\left(400 \mathrm{MHz}, \mathrm{CDCl}_{3}\right): 4.24(\mathrm{~s}, 1 \mathrm{H}, \mathrm{H}-1), 3.48\left(\mathrm{dd}, \mathrm{J}=12.0\right.$ and $\left.10.8 \mathrm{~Hz}, 3 \mathrm{H}, \mathrm{CH}_{3}-10\right)$, 3.27 (d, J = 3.6 Hz, 1H, H-2), 3.09 (d, J = 3.2 Hz, 1H, H-3), 2.74 (q, J = 7.2 Hz, 1H, H-7), 1.23-1.39 (m, 2H, $\left.\mathrm{CH}_{2}-5\right), 1.18$ (s, 3H, $\left.\mathrm{CH}_{3}-12\right), 1.06\left(\mathrm{~d}, \mathrm{~J}=7.2 \mathrm{~Hz}, 3 \mathrm{H}, \mathrm{CH}_{3}-11\right), 0.96\left(\mathrm{~s}, 3 \mathrm{H}, \mathrm{CH}_{3}-9\right),{ }^{13} \mathrm{C} \mathrm{NMR}(100 \mathrm{MHz}$, $\mathrm{CDCl}_{3}$ ): 178.03 (C-8), 79.17 (C-1), 71.26 (C-10), 58.18 (C-3), 52.40 (C-2), 40.23 (C-7), 39.37 (C-6), 33.97 (C-4), 33.07 (C-5), 23.69 (C-9), 21.68 (C-12), 7.30 (C-11), ESIHRMS: calcd for $\mathrm{C}_{11} \mathrm{H}_{18} \mathrm{O}_{4} \mathrm{Na}, \mathrm{m} / z 249.1103$ $(\mathrm{M}+\mathrm{H})^{+}$, found 249.1094. (Supplementary Materials, Figures S33-S38).

\subsection{Bioassay}

Tests were made using the strains of the bacteria, Escherichia coli $\mathrm{C} 1$ and Staphylococcus aureus; yeast, Candida albicans KL-1; and filamentous fungi, Alternaria alternate, Fusarium linii A3, and Aspergillus niger XP, which came from the collection of the Department of Biotechnology and Food Microbiology, Wroclaw University of Environmental and Life Sciences. These tests were performed on the automated Bioscreen C system (Automated Growth Curve Analysis System, Lab Systems, Turku, Finland) following the procedure described below. The bacterial cultures were cultured in a liquid broth containing $1.5 \%$ of dry bullion (Biocorp, Warszawa, Poland) and $1 \%$ of glucose dissolved in distilled water for $48 \mathrm{~h}$. Yeast and fungi were cultured in YPG medium containing $1 \%$ of yeast extract, $1 \%$ of bacteriological peptone, and $1 \%$ of glucose dissolved in distilled water for 48 and $96 \mathrm{~h}$, respectively. The mixture of $280 \mu \mathrm{L}$ of culture medium and $10 \mu \mathrm{L}$ of cells or spore solution (final density $1 \times 10^{6}$ cells $\mathrm{mL}^{-1}$ ) was placed in the $300 \mu \mathrm{L}$ wells of Bioscreen plates. Tested lactones after being dissolved in $10 \mu \mathrm{L}$ dimethyl sulphoxide were used at a final concentration of $0.1 \%(w / v)$. The temperatures were controlled to $25^{\circ} \mathrm{C}$ for filamentous fungi and $30{ }^{\circ} \mathrm{C}$ for bacteria and yeasts. The cell cultures were placed on a continuous shaker and the optical densities of the cell suspensions were measured automatically at $560 \mathrm{~nm}$ every $30 \mathrm{mins}$ for 2 to 4 days. Each culture was performed in three replicates. Data was analyzed using spreadsheet software (Excel 2010) and the means for three replicates of each type of culture medium were calculated. On the basis of mean values, growth curves were generated 
for each test strain. These curves were compared to the curves obtained for control cultures consisting of medium with the addition of dimethyl sulfoxide.

For all cases in which complete growth inhibition of microorganisms in the screening procedure was observed $(\triangle \mathrm{OD}=0)$, the minimal inhibitory concentration (MIC) values were specified. MIC was determined by the dilution method. Sterile 100-well microtiter plates with a nutrient broth with glucose (bacteria) or YM (yeast, filamentous fungi) medium (5\% of bacteriological peptone, 3\% of yeast extract, $3 \%$ of malt extract, $10 \%$ of glucose and $20 \%$ of agar) were inoculated with a standardized cell suspension of fungal spores of $1 \times 10^{5} \mathrm{cell} / \mathrm{mL}$, and supplemented with suitable lactones at the concentration range from 0.0075 to $0.1 \mathrm{mg} / \mathrm{mL}$, prepared with two-fold serial dilution. The analysis was conducted in three replicates. The plates were incubated at $25^{\circ} \mathrm{C}$ for $72 \mathrm{~h}$. The results were measured in Bioscreen $C$ at a $560 \mathrm{~nm}$ wavelength. The minimal inhibitory concentration was defined as the lowest concentration of a tested compound that completely restricted the growth of the microorganism. In order to verify the obtained results, microbial cultures subjected to each concentration of lactones were inoculated onto nutrient broth with glucose or YM plates and incubated as described above.

\section{Conclusions}

Two known unsaturated lactones ( $\mathbf{1}$ and $\mathbf{2})$ were biotransformed in cultures, seven strains of the Pleurotus genus. In case of lactone $\mathbf{1}$, the formation of a new hydroxylactone $\mathbf{3}$ and a known epoxylactone $\mathbf{4}$ was observed. Lactone $\mathbf{2}$ was transformed into the known hydroxylactone $\mathbf{5}$ and epoxylactone 6, and two new epoxy-hydroxylactones 7 and 8 . During the research, it turned out, that fungi of the Pleurotus genus were capable of completely converting the substrate within 7 days. As it was mentioned earlier, filamentous fungi of the genus Fusarium, Penicilium, Absidia, and Syncephalastrum needed 14 days for this. Lactones 3 and 4 were formed with high enantiomeric excess, and lactones $\mathbf{5}$, 6, and 8 with small excess; however, all with the predominance of (-)-enantiomer. Both the unsaturated lactones and hydroxy- and epoxy- derivatives were capable of completely inhibiting the growth of two strains of A. alternata and F. linii.

Supplementary Materials: The following are available online at http://www.mdpi.com/2073-4344/9/8/643/s1. Figure $\mathrm{S} 1 .{ }^{1} \mathrm{H}$ NMR $\left(400 \mathrm{MHz}, \mathrm{CDCl}_{3}\right)$ spectrum of unsaturated lactone 1, Figure $\mathrm{S} 2 .{ }^{13} \mathrm{C} \mathrm{NMR}\left(100 \mathrm{MHz}, \mathrm{CDCl}_{3}\right)$ spectrum of unsaturated lactone 1, Figure S3. ${ }^{1} \mathrm{H}$ NMR $\left(400 \mathrm{MHz}, \mathrm{CDCl}_{3}\right)$ spectrum of unsaturated lactone 2, Figure $\mathrm{S}^{13}{ }^{13} \mathrm{C} \mathrm{NMR}\left(100 \mathrm{MHz}, \mathrm{CDCl}_{3}\right)$ spectrum of unsaturated lactone 2, Figure $55 .{ }^{1} \mathrm{H} \mathrm{NMR}\left(400 \mathrm{MHz}, \mathrm{CDCl}_{3}\right)$ spectrum of hydroxylactone 3, Figure S6. COSY $\left(100 \mathrm{MHz}, \mathrm{CDCl}_{3}\right)$ spectrum of hydroxylactone 3, Figure S7. HMQC $\left(100 \mathrm{MHz}, \mathrm{CDCl}_{3}\right)$ spectrum of hydroxylactone 3, Figure $\mathrm{S} 8 .{ }^{13} \mathrm{C} \mathrm{NMR}\left(100 \mathrm{MHz}, \mathrm{CDCl}_{3}\right)$ spectrum of hydroxylactone 3, Figure S9. HRMS spectrum of hydroxylactone 3, Figure S10. IR spectrum of hydroxylactone 3 Figure S11. ${ }^{1} \mathrm{H}$ NMR $\left(400 \mathrm{MHz}, \mathrm{CDCl}_{3}\right)$ spectrum of epoxylactone 4-A+B, Figure S12. COSY $\left(100 \mathrm{MHz}, \mathrm{CDCl}_{3}\right)$ spectrum of epoxylactone $\mathbf{4}-\mathbf{A}+\mathbf{B}$, Figure S13. HMQC (100 MHz, $\left.\mathrm{CDCl}_{3}\right)$ spectrum of epoxylactone $\mathbf{4}-\mathbf{A}+\mathbf{B}$, Figure S14. ${ }^{13} \mathrm{C}$ NMR $\left(100 \mathrm{MHz}, \mathrm{CDCl}_{3}\right)$ spectrum of epoxylactone 4-A+B, Figure S15. ${ }^{1} \mathrm{H}$ NMR $(400 \mathrm{MHz}$, $\left.\mathrm{CDCl}_{3}\right)$ spectrum of epoxylactone 4-B, Figure S16. COSY $\left(100 \mathrm{MHz}, \mathrm{CDCl}_{3}\right)$ spectrum of epoxylactone 4-B, Figure S17. HMQC $\left(100 \mathrm{MHz}, \mathrm{CDCl}_{3}\right)$ spectrum of epoxylactone 4-B, Figure $\mathrm{S} 18 .{ }^{13} \mathrm{C} \mathrm{NMR}\left(100 \mathrm{MHz}, \mathrm{CDCl}_{3}\right)$ spectrum of epoxylactone 4-B, Figure S19. $1 \mathrm{H}$ NMR $\left(400 \mathrm{MHz}, \mathrm{CDCl}_{3}\right)$ spectrum of hydroxylactone 5, Figure S20. COSY $\left(100 \mathrm{MHz}, \mathrm{CDCl}_{3}\right)$ spectrum of hydroxylactone 5, Figure $\mathrm{S} 21$. $\mathrm{HMQC}\left(100 \mathrm{MHz}, \mathrm{CDCl}_{3}\right)$ spectrum of hydroxylactone 5, Figure S22. ${ }^{13} \mathrm{C}$ NMR $\left(100 \mathrm{MHz}, \mathrm{CDCl}_{3}\right)$ spectrum of hydroxylactone 5, Figure S23. ${ }^{1} \mathrm{H}$ NMR (400 MHz, $\mathrm{CDCl}_{3}$ ) spectrum of epoxylactone 6, Figure S24. COSY (100 MHz, $\mathrm{CDCl}_{3}$ ) spectrum of epoxylactone 6, Figure S25. HMQC (100 MHz, $\left.\mathrm{CDCl}_{3}\right)$ spectrum of epoxylactone 6, Figure S26. ${ }^{13} \mathrm{C}$ NMR $\left(100 \mathrm{MHz}, \mathrm{CDCl}_{3}\right)$ spectrum of epoxylactone 6, Figure S27. ${ }^{1} \mathrm{H}$ NMR $\left(400 \mathrm{MHz}, \mathrm{CDCl}_{3}\right)$ spectrum of epoxy-hydroxylactone 7, Figure $\mathrm{S} 28$. COSY (100 MHz, CDCl $)$ spectrum of epoxy-hydroxylactone 7, Figure S29. HMQC (100 MHz, CDCl $)$ spectrum of epoxy-hydroxylactone 7, Figure $\mathrm{S} 30 .{ }^{13} \mathrm{C} \mathrm{NMR}\left(100 \mathrm{MHz}, \mathrm{CDCl}_{3}\right)$ spectrum of epoxy-hydroxylactone 7, Figure S31. HRMS spectrum of epoxy-hydroxylactone 7, Figure S32. IR spectrum of epoxy-hydroxylactone 7, Figure S33. ${ }^{1} \mathrm{H}$ NMR $\left(400 \mathrm{MHz}, \mathrm{CDCl}_{3}\right)$ spectrum of epoxy-hydroxylactone 8, Figure $\mathrm{S} 34$. COSY $\left(100 \mathrm{MHz}, \mathrm{CDCl}_{3}\right)$ spectrum of epoxy-hydroxylactone 8, Figure $\mathrm{S} 35$. HMQC ( $\left.100 \mathrm{MHz}, \mathrm{CDCl}_{3}\right)$ spectrum of epoxy-hydroxylactone 8, Figure S36. ${ }^{13} \mathrm{C}$ NMR $\left(100 \mathrm{MHz}, \mathrm{CDCl}_{3}\right)$ spectrum of epoxyhydroxylactone 8, Figure S37. HRMS spectrum of epoxy-hydroxylactone 8, Figure S38. IR spectrum of epoxy-hydroxylactone 8 Figure S39. Chiral chromatogram of hydroxylactone 3, Figure S40. Chiral chromatogram of epoxylactone 4, Figure S41. Chiral chromatogram of hydroxylactone 5, Figure S42. Chiral chromatogram of epoxylactone 6, Figure S43. Chiral chromatogram epoxy-hydroxylactone 8, Figure S44. The assessment of the effects of the lactones 1-8 on the growth of E. coli, Figure S45. The assessment of the effects of the lactones 1-8 on the growth of S. aureus, Figure S46. The assessment 
of the effects of the lactones 1-8 on the growth of C. albicans, Figure S47. The assessment of the effects of the lactones 1-8 on the growth of Alternaria sp., Figure S48. The assessment of the effects of the lactones 1-8 on the growth of F. linii, Figure S49. The assessment of the effects of the lactones 1-8 on the growth of $A$. niger.

Author Contributions: M.C. conceived and designed the experiments and analyzed the data, W.M., K.W. and A.K. performed the experiments; B.Z. performed the biological analysis, G.M. performed the high resolution mass spectrometry analysis, E.G. takes care of the mushroom collection, E.G. and S.P. contributed to the discussion of results. M.G., W.M. and K.W. wrote the paper. All authors read and approved the final manuscript.

Funding: This research received no external funding.

Acknowledgments: Special thanks to hab. Janusz Kalbarczyk for providing a collection of fungi. Publication supported by the Wroclaw Centre of Biotechnology under the Leading National Research Centre (KNOW) programme for years 2014-2018.

Conflicts of Interest: The authors declare no conflict of interest.

\section{References}

1. Fernandes, A.; Barros, L.; Martins, A.; Herbert, P.; Ferreira, I.C.F.R. Nutritional characterisation of Pleurotus ostreatus (Jacq. ex Fr.) P. Kumm. produced using paper scraps as substrate. Food Chem. 2015, 169, 396-400. [CrossRef] [PubMed]

2. Mbassi, J.E.G.; Mobou, E.Y.; Ngome, F.A.; Sado, K.S.L. Effect of substrates on nutritional composition and functional properties of Pleurotus ostreatus. Curr. Res. Agric. Sci. 2018, 5, 15-22. [CrossRef]

3. Bonatti, M.; Karnopp, P.; Soares, H.M.; Furlan, S.A. Evaluation of Pleurotus ostreatus and Pleurotus sajor-caju nutritional characteristics when cultivated in different lignocellulosic wastes. Food Chem. 2004, 88, 425-428. [CrossRef]

4. Maftoun, P.; Johari, H.; Soltani, M.; Malik, R.; Othman, N.Z.; El Enshasy, H.A. The edible mushroom Pleurotus spp.: I. Biodiversity and nutritional values. Int. J. Biotechnol. Wellness 2015, 4, 67-83.

5. Alarcon, J.; Aguila, S.; Arancibia-Avila, P.; Fuentes, O.; Zamorano-Ponce, E.; Hernandez, M. Production and purification of statins from Pleurotus ostreatus (Basidiomycetes) strains. Z. Nat. C 2003, 58, 62-64. [CrossRef]

6. Javaid, A.; Bajwa, R.; Shafique, U.; Anwar, J. Removal of heavy metals by adsorption on Pleurotus ostreatus. Biomass Bioenergy 2011, 35, 1675-1682. [CrossRef]

7. Jin, Y.; Teng, C.; Yu, S.; Song, T.; Dong, L.; Liang, J.; Bai, X.; Liu, X.; Hu, X.; Qu, J. Batch and fixed-bed biosorption of Cd(II) from aqueous solution using immobilized Pleurotus ostreatus spent substrate. Chemosphere 2018, 191, 799-808. [CrossRef]

8. Kocaoba, S.; Arisoy, M. Biosorption of cadmium(II) and lead(II) from aqueous solutions using Pleurotus ostreatus immobilized on bentonite. Sep. Sci. Technol. 2018, 53, 1703-1710. [CrossRef]

9. Jackson, L.W., III; Pryor, B.M. Degradation of aflatoxin B1 from naturally contaminated maize using the edible fungus Pleurotus ostreatus. AMB Express 2017, 7, 110. [CrossRef]

10. Pereira, P.M.; Sobral Teixeira, R.S.; de Oliveira, M.A.L.; da Silva, M.; Ferreira-Leitão, V.S. Optimized atrazine degradation by Pleurotus ostreatus INCQS 40310: An alternative for impact reduction of herbicides used in sugarcane crops. J. Microb. Biochem. Technol. 2013, 12, 006. [CrossRef]

11. Purnomo, A.S.; Nawfa, R.; Martak, F.; Shimizu, K.; Kamei, I. Biodegradation of aldrin and dieldrin by the white-rot fungus Pleurotus ostreatus. Curr. Microbiol. 2017, 74, 320-324. [CrossRef]

12. Tlécuitl-Beristain, S.; García-Dávila, J.; Santacruz-Juárez, E.; González-Pérez, M.; Gutiérrez-Ruíz, C.; Sánchez, C. Kinetics and pathway of biodegradation of dibutyl phthalate by Pleurotus ostreatus. Fungal Biol. 2018, 122, 991-997. [CrossRef]

13. Ahuactzin-Pérez, M.; Tlecuitl-Beristain, S.; García-Dávila, J.; Santacruz-Juárez, E.; González-Pérez, M.; Gutiérrez-Ruíz, M.C.; Sánchez, C. A novel biodegradation pathway of the endocrine-disruptor di(2-ethylhexyl) phthalate by Pleurotus ostreatus based on quantum chemical investigation. Ecotoxicol. Environ. Saf. 2018, 147, 494-499. [CrossRef]

14. de Freitas, E.N.; Bubna, G.A.; Brugnari, T.; Kato, C.; Nolli, M.; Rauen, T.; Moreira, R.; Peralta, R.; Bracht, A.; de Souza, C.G.M.; et al. Removal of bisphenol A and evaluation of ecotoxicity of degradation products by laccases from Pleurotus ostreatus and Pleurotus pulmonarius. Chem. Eng. J. 2017, 330, 1361-1369. [CrossRef]

15. Fraatz, M.A.; Riemer, S.J.L.; Stöber, R.; Kaspera, R.; Nimtz, M.; Berger, R.G.; Zorn, H. A novel oxygenase from Pleurotus sapidus transforms valencene to nootkatoneJournal. J. Mol. Catal. B Enzym. 2009, 61, $202-207$. [CrossRef] 
16. Krügener, S.; Krings, U.; Zorn, H.; Berger, R.G. A dioxygenase of Pleurotus sapidus transforms (+)-valencene regio-specifically to (+)-nootkatone via a stereo-specific allylic hydroperoxidation. Bioresour. Technol. 2010, 101, 457-462. [CrossRef]

17. Lehnert, N.; Krings, U.; Sydes, D.; Wittig, M.; Berger, R.G. Bioconversion of car-3-ene by a dioxygenase of Pleurotus sapidus. J. Biotechnol. 2012, 159, 329-335. [CrossRef]

18. Weidmann, V.; Schaffrath, M.; Zorn, H.; Rehbein, J.; Maison, W. Elucidation of the regio- and chemoselectivity of enzymatic allylic oxidations with Pleurotus sapidus-Conversion of selected spirocyclic terpenoids and computational analysis. Beilstein J. Org. Chem. 2013, 9, 2233-2241. [CrossRef]

19. Béni, Z.; Dékány, M.; Kovács, B.; Csupor-Löffler, B.; Zomborszki, Z.P.; Kerekes, E.; Szekeres, A.; Urbán, E.; Hohmann, J.; Ványolós, A. Bioactivity-guided isolation of antimicrobial and antioxidant metabolites from the mushroom Tapinella atrotomentos. Molecules 2018, 23, 1082. [CrossRef]

20. Wang, X.; Sun, K.; Wang, B. Bioactive pimarane diterpenes from the arctic fungus Eutypella sp. D-1. Chem. Biodivers. 2018, 15, e1700501. [CrossRef]

21. Huang, C.Y.; Ahmed, A.F.; Su, J.H.; Sung, P.J.; Hwang, T.L.; Chiang, P.L.; Dai, C.F.; Liaw, C.C.; Sheu, J.H. Bioactive new withanolides from the cultured soft coral Sinularia brassica. Bioorg. Med. Chem. Lett. 2017, 27, 3267-3271. [CrossRef]

22. Anwar, L.; Efdi, M.; Ninomiya, M.; Ibrahim, S.; Putra, D.P.; Tanaka, K.; Koketsu, M. Labdane diterpene lactones of Vitex pubescens and their antileukemic properties. Med. Chem. Res. 2017, 26, 2357-2362. [CrossRef]

23. Formisano, C.; Sirignano, C.; Rigano, D.; Chianese, G.; Zengin, G.; Seo, E.J.; Efferth, T.; Taglialatela-Scafati, O. Antiproliferative activity against leukemia cells of sesquiterpene lactones from the Turkish endemic plant Centaurea drabifolia subsp. Detonsa. Fitoterapia 2017, 12, 98-102. [CrossRef]

24. Formisano, C.; Sanna, C.; Ballero, M.; Chianese, G.; Sirignano, C.; Rigano, D.; Millan, E.; Munoz, E.; Taglialatela-Scafati, O. Anti-inflammatory sesquiterpene lactones from Onopordum Illyricum L. (Asteraceae), an Italian medicinal plant. Fitoterapia 2017, 116, 61-65. [CrossRef]

25. Svensson, D.; Lozano, M.; Almanza, G.R.; Nilsson, B.O.; Sterner, O.; Villagomez, R. Sesquiterpene lactones from Ambrosia arborescens Mill. inhibit pro-inflammatory cytokine expression and modulate NF- $\mathrm{K}$ signaling in human skin cells. Phytomedicine 2018, 50, 118-126. [CrossRef]

26. Kim, G.S.; Ko, W.; Kim, J.W.; Jeong, M.H.; Ko, S.K.; Hur, J.S.; Oh, H.; Jang, J.H.; Ahn, J.S. Bioactive $\alpha$-pyrone derivatives from the endolichenic fungus Dothideomycetes sp. EL003334. J. Nat. Prod. 2018, 81, 1084-1088. [CrossRef]

27. Silva, G.H.; Zeraik, M.L.; de Oliveira, C.M.; Teles, H.L.; Trevisan, H.C.; Pfenning, L.H.; Nicolli, C.P.; Young, M.C.M.; Mascarenhas, Y.P.; Abreu, L.M.; et al. Lactone derivatives produced by a Phaeoacremonium sp., an endophytic fungus from Senna spectabilis. J. Nat. Prod. 2017, 80, 1674-1678. [CrossRef]

28. Gładkowski, W.; Grabarczyk, M.; Wińska, K.; Ratuś, B.; Białońska, A.; Ciunik, Z.; Wawrzeńczyk, C. Lactones 26 [1]: Stereoselective microbial epoxidation of unsaturated bicyclic $\gamma$-lactones with the alkylsubstituted cyclohexane system. J. Mol. Catal. B Enzym. 2007, 49, 79-87. [CrossRef]

29. Wińska, K.; Grabarczyk, M.; Mączka, W.; Żarowska, B.; Maciejewska, G.; Anioł, M. Influence of the structure of lactones with methylcyclohexene and dimethylcyclohexene ring on their biotransformation and antimicrobial activity. Z. Nat. C 2017, 72, 209-218. [CrossRef]

30. Wińska, K.; Grabarczyk, M.; Mączka, W.; Żarowska, B.; Maciejewska, G.; Anioł, M. Antimicrobial activity of new bicyclic lactones with three or four methyl groups obtained both synthetically and biosynthetically. $J$. Saudi Chem. Soc. 2018, 22, 363-371. [CrossRef]

31. Wińska, K.; Grabarczyk, M.; Mączka, W.; Kondas, A.; Maciejewska, G.; Bonikowski, R.; Anioł, M. Synthesis and biotransformation of bicyclic unsaturated lactones with three or four methyl groups. Molecules 2017, 22, 147. [CrossRef]

Sample Availability: Samples of the compounds 1-8 are available from the authors. 